\title{
Risk Factor Prevalence of Late Onset Preeclampsia in Dr. Soetomo General Hospital Surabaya
}

\author{
Fajrinka Pralampito ${ }^{1}$, Agus Sulistyono ${ }^{2^{*}} \mathbb{D}$, Sri Purwaningsih $^{3}$
}

${ }^{1}$ Faculty of Medicine, Universitas Airlangga, Surabaya, Indonesia.

2Department of Obstetrics and Gynecology, Faculty of Medicine, Universitas Airlangga/Dr. Soetomo General Hospital, Surabaya, Indonesia.

${ }^{3}$ Department of Pharmacology, Universitas Airlangga, Surabaya, Indonesia.

\section{A B S T R A C T}

Introduction: Preeclampsia is a condition of hypertension that occurs after 20 weeks of gestation, followed by the detection of protein in the urine sample, and is one of the major causes of maternal mortality. It is categorized, based on time of gestation, into 2-stage are early and late-onset. One of the more accessible tools in diagnosing and also preventing preeclampsia is by its risk factors. The aim of this study was to observe the appearance of some of the risk factors in patients with lateonset preeclampsia and to allow a better approach in patients with said comorbidities.

Methods: This was a descriptive observational study. The sample used was 35 patients diagnosed with late-onset preeclampsia in Dr. Soetomo General Hospital Surabaya from January to December 2016.

Results: Among 35 patients diagnosed with late-onset preeclampsia, obesity $(65.71 \%)$ appeared the most. Maternal age (37.15\%) and primigravida $(28.57 \%)$ appeared in second and third places. Chronic hypertension appeared only in 6 (17.14\%) patients, whereas multiple pregnancies appeared in $3(8.57 \%)$. Both patients with a history of previous preeclampsia and diabetes mellitus only appeared once $(2.86 \%)$.

Conclusion: Obesity has the most appearance in patients with late-onset preeclampsia, followed by maternal age and primigravida.

\section{* Correspondence: agussuldr@yahoo.com}

JUXTA: Jurnal IImiah Mahasiswa Kedokteran Universitas Airlangga

p-ISSN: 1907-3623; e-ISSN: 2684-9453

DOI: $10.20473 /$ juxta.V12I22021.54-56

Open access under Creative Commons Attribution-ShareAlike 4.0 International License (CC-BY-SA)

\section{ARTICLE INFO}

Article history:

Received 3 March 2021

Received in revised form 8 July 2021

Accepted 1 August 2021

Available online 31 August 2021

\section{Keywords:}

Late onset,

Maternal health,

Maternal mortality,

Obesity,

Preeclampsia. 


\section{Introduction}

Preeclampsia, also known as hypertension in pregnancy, is a condition of increased blood pressure after 20 weeks of gestation. This disorder, in its severe state, may eventually lead to other organ failures. Preeclampsia signs consist of high proteinuria, thrombocytopenia, upper abdomen pain, or severe headache. ${ }^{1}$ The criteria of preeclampsia increase blood pressure after 20 weeks of gestation, proteinuria of greater than or equal to $300 \mathrm{mg} / \mathrm{dL}$ in a 24-hour urine specimen, with the systolic blood pressure of $140 \mathrm{mmHg}$ or diastolic blood pressure of $90 \mathrm{mmHg}^{2}$

Preeclampsia, based on its onset, can be divided into early and late-onset. Early-onset preeclampsia is defined as increased blood pressure before 34 weeks of gestation. ${ }^{3}$ Whereas late-onset preeclampsia develops within or after 34 weeks of gestation. ${ }^{4}$

The etiology of preeclampsia is still unknown, and there are only theories used in determining preeclampsia. ${ }^{5}$ The most common theory used is abnormal spiral artery modification. Although there are no specific etiologies of preeclampsia, its risk factors can be used to monitor the possible development of preeclampsia. Some of the known factors of preeclampsia are maternal age, ${ }^{6,7}$ history of

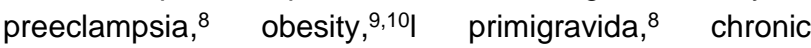
hypertension, ${ }^{11}$ multiple pregnancy ${ }^{5}$ and history of diabetes mellitus. $^{12}$

\section{Methods}

This was a descriptive observational study conducted in Dr. Soetomo General Hospital Surabaya. The variables used were risk factors of preeclampsia which consisted of maternal age, history of preeclampsia, obesity, primigravida, chronic hypertension, multiple pregnancies, and diabetes mellitus. The population was all patients diagnosed with preeclampsia in Dr. Soetomo General Hospital Surabaya from January to December 2016. Data were obtained using patients' medical records that had received approval of ethical clearance from the ethics committee of Faculty of Medicine Universitas Airlangga and Dr. Soetomo General Hospital Surabaya. Inclusion criteria were patients with late-onset preeclampsia and had one or more of the risk factors mentioned previously. Exclusion criteria were patients with early-onset preeclampsia, patients without risk factors mentioned, and/or patients with insufficient data. The data obtained were analyzed and presented in the form of a table.

\section{Results}

Table 1. Risk factors on patient with late onset preeclampsia

\begin{tabular}{lc}
\hline Risk Factors & $\mathbf{n = 3 5}$ \\
\hline Maternal age & \\
$\quad<18$ & $0(0 \%)$ \\
$>35$ & $13(37.15 \%)$ \\
History of Preeclampsia & $1(2.86 \%)$ \\
Obesity & $23(65.71 \%)$ \\
Primigravida & $10(28.57 \%)$ \\
Chronic Hypertension & $6(17.14 \%)$ \\
Multiple Pregnancy & $3(8.57 \%)$ \\
\hline
\end{tabular}

As seen from the table, the results revealed that obesity $(65.71 \%)$ had the most appearance among 35 patients diagnosed with late-onset preeclampsia, followed by maternal age $(37.15 \%)$. Primigravida $(28.57 \%)$, chronic hypertension (17.14\%), multiple pregnancies (8.57\%), history of preeclampsia $(2.86 \%)$, and history of diabetes mellitus $(2.86 \%)$ also appeared with less frequency.

\section{Discussion}

Obesity is more common in late-onset preeclampsia. A study in Missouri about obesity in preeclampsia patients revealed that $4.1 \%$ of them are detected in late-onset preeclampsia, rather than $0.4 \%$ of them in early onset. ${ }^{13}$ It is known that in a patient with obesity, a dysfunction in nitrite oxide production is impaired. This leads to vascular endothelial dysfunction. ${ }^{14}$ There is a similar result shown in this study.

A study in Reunion Highland suggests that the occurrence of preeclampsia in high-risk gestational age has low relevancy in late or early onset preeclampsia. ${ }^{15}$ In comparison, this study's result stated that high-risk gestational age came second in appearance in late-onset preeclampsia. The difference might be caused by the samples collected not exclusively carry single risk factors. The only significant difference in Reunion Highland's study is chronic hypertension which is more related to early-onset preeclampsia. High-risk gestational age is maternal age $<18$ years old and $\geq 35$ years old. A study in India shows an increased risk of preeclampsia in pregnant women $<20$ years old. ${ }^{16}$ Although there was no sample in this study that met this age criterion, it can also be kept in mind why pregnant women in those critical ages must be observed intensively. Another study suggests that women aged $\geq 40$ years old have a two-fold increase in the risk of developing preeclampsia, ${ }^{17}$ which is also shown in this study.

These results can be put into consideration in facing patients with said risk factors. Physicians will promote ideal 
pregnancy conditions in a certain way that is easier for people to understand and utilize early detection in more of the preventable risk factors that play a role in preeclampsia development.

\section{Conclusion}

Obesity as a risk factor appears the most amongst others, followed by maternal age and primigravida. Mothers' lifestyle can cause this, which is known to have contributed to late-onset preeclampsia.

\section{CONFLICT OF INTEREST}

The author stated there is no conflict of interest in this study.

\section{REFERENCES}

1. (ACOG) TAC of O and G. Preeclampsia and High Blood Pressure During Pregnancy. Frequently Asked Questions, https://www.acog.org/womenshealth/faqs/preeclampsia-and-high-bloodpressure-duringpregnancy?utm_source=redirect\&utm_medium $=\mathrm{w}$ eb\&utm_campaign=otn (2016).

2. Uzan J, Carbonnel M, Piconne O, et al. Pre-eclampsia: Pathophysiology, Diagnosis, and Management. Vasc Health Risk Manag 2011; 7: 467-474.

3. Simard JF, Arkema E V, Nguyen C, et al. Early-Onset Preeclampsia in Lupus Pregnancy. Paediatr Perinat Epidemiol 2017; 31: 29-36.

4. Raymond D, Peterson E. A Critical Review of EarlyOnset and Late-Onset Preeclampsia. Obstet Gynecol Surv 2011; 66: 497-506.

5. Prawirohardjo S. IImu Kebidanan. 4th ed. Jakarta: P.T. Bina Pustaka Sarwono Prawirohardjo, 2016.
6. Lamminpää R, Vehviläinen-Julkunen $\mathrm{K}$, Gissler M, et al. Preeclampsia Complicated by Advanced Maternal Age: A Registry-Based Study on Primiparous Women in Finland 1997-2008. BMC Pregnancy Childbirth 2012; 12: 47.

7. Cavazos-Rehg PA, Krauss MJ, Spitznagel EL, et al. Maternal Age and Risk of Labor and Delivery Complications. Matern Child Health J 2015; 19 : 1202-1211.

8. Hernández-Díaz S, Toh S, Cnattingius S. Risk of PreEclampsia in First and Subsequent Pregnancies: Prospective Cohort Study. BMJ 2009; 338: b2255.

9. Leddy MA, Power ML, Schulkin J. The Impact of Maternal Obesity on Maternal and Fetal Health. Rev Obstet Gynecol 2008; 1: 170-178.

10. Sulistyowati S. Early and Late Onset Preeclamsia: What did really Matter? J Gynecol Womens Heal; 5. Epub ahead of print 27 June 2017. DOI: 10.19080/JGWH.2017.05.555670.

11. Association AP. Hypertension in Pregnancy: Executive Summary. Obstet Gynecol 2013; 122: 2-8.

12. Cunningham FG, Leveno KJ, Bloom SL, et al. Williams Obstetrics. 2014; 408-433.

13. Mbah AK, Kornosky JL, Kristensen S, et al. SuperObesity and Risk for Early and Late PreEclampsia. BJOG 2010; 117: 997-1004.

14. Boden G. Obesity and Free Fatty Acids. Endocrinol Metab Clin North Am 2008; 37: 635-46, viii-ix.

15. lacobelli $S$, Bonsante $F$, Robillard P-Y. Comparison of Risk Factors and Perinatal Outcomes in Early Onset and Late Onset Preeclampsia: A Cohort Based Study in Reunion Island. J Reprod Immunol 2017; 123: 12-16.

16. K R, Gandhi S, Rao V. Socio-Demographic and Other Risk Factors of Pre Eclampsia at a Tertiary Care Hospital, Karnataka: Case Control Study. J Clin Diagn Res 2014; 8: JC01-4.

17. Duckitt K, Harrington D. Risk Factors for Pre-Eclampsia at Antenatal Booking: Systematic Review of Controlled Studies. BMJ 2005; 330: 565. 